\title{
PROPERTIES OF ICE-CREAM FORTIFIED WITH ZINC AND LACTOBACILLUS CASEI ${ }^{*}$
}

\author{
Hamid R. Gheisari ${ }^{\boxplus 凶}$, Leila Ahadi², Sanaz Khezli², Tayebeh Dehnavi ${ }^{4}$ \\ ${ }^{1}$ Department of Food Hygiene, School of Veterinary Medicine, Shiraz University \\ 71348 Shiraz, Iran \\ ${ }^{2}$ Department of Food Science, Azad University \\ Yasuj, Iran \\ ${ }^{3}$ Ramak Bita Ice Cream Company \\ 71346-964 Shiraz, Iran
}

\begin{abstract}
Background. In this study, the possible effects of zinc on physicochemical properties of ice cream and the survival of Lactobacillus casei during a 90 days storage at $-18^{\circ} \mathrm{C}$ was investigated.

Material and methods. Samples were divided into four experimental groups as follows: control, zinc fortified ice cream, probiotic ice cream, zinc fortified and probiotic ice cream. The physicochemical, texture, organoleptic properties and the survival of probiotics, were investigated.

Results. Results showed that the addition of zinc did not affect the textural properties of ice creams. Viscosity and $\mathrm{pH}$ were independently decreased in all groups in the presence of zinc. A significant increase in the lipid oxidation rate especially in the zinc fortified group was also observed. The probiotic counts were maintained above the least advised quantities $\left(10^{6} \mathrm{cfu} / \mathrm{g}\right)$ which were subsequently reduced following the three months of storage. In the zinc fortified samples, the counts were higher compared to the other groups with no zinc addition. The addition of probiotics and zinc had no significant effect on the sensory properties of ice cream.
\end{abstract}

Conclusion. As a final conclusion, the commercial production of zinc fortified ice cream is recommended.

Key words: ice cream, zinc, fortification, Lactobacillus casei

\section{INTRODUCTION}

Milk and other dairy products are considered to present either poor sources of different trace elements or their levels are not adequate to meet the human needs for a healthy human body (Jayasekara et al., 1992). Consequently, people should obtain their trace element needs from the products other than milk or the fortified dairy products. The fortification of food has been frequently used to enhance the minerals and vitamins levels and to get rid of the deficiencies. Among all various trace elements, zinc is very important and has an effective role in the human nutrition and body metabolism. This element is needed to catalyze more than 100 enzymes (Kahraman and Ustunol, 2012; Saper and Rash, 2009; Qin et al., 2009) and is important for immune function, protein synthesis, wound healing, DNA synthesis, and cell division (Hunt and

\footnotetext{
*The authors gratefully acknowledge the instrumental support for this work provided by the Ramak Bita Ice Cream Company.
} 
Nielsen, 2009; Walingo, 2009). During pregnancy, zinc is needed for normal growth and the development of newborns and it is needed during childhood and adolescence (Simmer and Thompson, 1985). For normal health and maintenance, we need to take zinc daily since the human body cannot store zinc (Rink and Gabriel, 2000; Salgueiro et al., 2000). We define probiotic food as the product containing viable probiotic micro-organisms in sufficient numbers assembled to reach an appropriate matrix (Gibson et al., 2004; Saxelin et al., 2003). In addition, adding probiotic cultures to the ice cream provides it with the advantage of being functional, in addition to make these products more valuable (Akin et al., 2007; Hekmat and McMahon, 1997; Kailasapathy and Sultana, 2003; Shah and Ravula, 2000). According to the American Council on Science and Health, "Functional foods can be considered to be those whole, fortified, enriched, or enhanced foods that provide health benefits beyond the provision of essential nutrients (for example, vitamins and minerals), when they are consumed at efficacious levels as part of a varied diet on a regular basis" (Hasler, 2002). Ice creams are considered as a nutritive food due to the presence of milk or fruits in its formulation, representing a source of proteins, vitamins, and minerals. The supplementation of ice cream with prebiotic ingredients or probiotic bacteria can add value to the product by providing functional appeal. Being well accepted by people, they usually consume these products daily. Thus many researchers have investigated the zinc fortification and the enrichment of different products (Abd-Rabou et al., 2010; Degheidi and Abd-Rabou, 1998; Hermansen et al., 1995). The purpose of the current study was to examine the zinc fortification effect on the viability of a commercial probiotic strain Lactobacillus casei, which was added to the ice cream. In addition the physicochemical properties and the sensory characteristics of ice creams were evaluated.

\section{MATERIAL AND METHODS}

\section{Experimental design}

Three probiotic, zinc fortified, zinc fortified and probiotic ice cream formulations were produced to compare with the regular ice cream as a control. The ice cream formulations were intended for the hard-texture product and identified as follows: Control group ice cream without any treatment, probiotic supplemented of Lactobacillus casei $(0.1 \%)$, zinc fortified $(150 \mathrm{mg}$ zinc per $\mathrm{kg}$ ), probiotic supplemented of Lactobacillus casei $(0.1 \%)$ plus zinc (150 mg zinc per $\mathrm{kg})$. The current recommended dietary allowance (RDA) for zinc in the United States is $11 \mathrm{mg}$ for men and $8 \mathrm{mg}$ for women per day based on the Food and Nutrition Board and Institute of Medicine (2001). These values are higher for pregnant and lactating women, at 12 and 13 mg per day, respectively (Jeejeebhoy, 2009). All productions were performed in triplicate.

\section{The ingredients and the probiotic strain for the ice cream manufacture}

Pasteurized and homogenized cow's milk (3.32 $\pm 0.4 \%$ fat) was obtained from the research and development unit of Ramak Dairy Company, Shiraz, Iran. The probiotic culture of Lactobacillus casei (ATCC 39392, Lyophylized) was obtained from CHR-Hansen (Horsholm, Denmark). The bacterial counts were determined after freezing as well as at the end of every 30 days during the 90 days storage at $-18^{\circ} \mathrm{C}$. Zinc sulfate (Merck, Germany) was used as the zinc element. Five zinc salts have obtained GRAS (Generally Recognized As Safe) status from the US Food and Drug Administration: zinc sulfate, zinc chloride, zinc gluconate, zinc oxide, and zinc stearate (Salgueiro et al., 2000). Among these, zinc oxide and zinc sulfate are the most commonly used (Hotz et al., 2005). Other ingredients were including skim milk (Ramak Dairy Company, Shiraz, Iran), the commercial sugar as sweetener (Industries Co., Marvdasht, Iran), vanilla for aroma development $(0.2 \%$, polar Bear, Shanghai, China), and the hydrogenated vegetable oil (8\%, Narges, Shiraz, Iran). Carboxy methyl cellulose (E466; Sunrose, Tokyo, Japan) and Panisol (Danisco, Copenhagen, Denmark) containing mono-and diglycerides (E 471), cellulose gum (E410), guar gum (E412), carrageenan (E407), tocopherol-rich extract (E306) and ascorbyl palmitate (E304) as the stabilizer-emulsifier were provided by a local ice cream factory (Ramak Co., Shiraz, Iran).

\section{Manufacture of ice cream}

The ice cream mixes were prepared in $3 \mathrm{~kg}$ batches. The liquid milk was heated to $60^{\circ} \mathrm{C}$ prior to being mixed with the solid ingredients. All the required 
ingredients were then thoroughly mixed with the milk. The mixes were pasteurized at $80^{\circ} \mathrm{C}$ for $15 \mathrm{~min}$, followed by cooling up to $60^{\circ} \mathrm{C}$ and dispersed along with stirring for 5 min using a simple mixer (Model 6490; Tefal, Rumilly, France). The ice cream mixes were subsequently cooled to room temperature and aged overnight at $4{ }^{\circ} \mathrm{C}$. The zinc element and the probiotic micro-organism $\left(10^{9} \mathrm{CFU} / \mathrm{g}\right)$ were added to the ice cream mixer prior to freezing. The ice cream mixes were whipped and frozen using a batch ice creammaker machine with the capacity of $3 \mathrm{~kg}$ without any additional aeration source (Model: BQL-12Y; Shanghai Lisong, Shanghai, China) at a constant speed (52 rpm) for about $40 \mathrm{~min}$. The temperature of soft ice cream had been reached to $-5^{\circ} \mathrm{C}$ at the end of freezing. The samples were finally packaged in the plastic containers, hardened at $-30^{\circ} \mathrm{C}$ for $2 \mathrm{~h}$ and stored at $-18^{\circ} \mathrm{C}$ for further use.

\section{Physicochemical analysis}

The $\mathrm{pH}$ of the ice cream was measured using a digital pH-meter at room temperature (Model $350 \mathrm{PH}$ Meter, Jenway, Dunmow, UK). Titratable acidity was calculated by titrating the sample with $0.1 \mathrm{~N}$ sodium hydroxide $(\mathrm{NaOH})$ using phenol phthalein as an indicator and expressed as the percent of lactic acid (AOAC, 2010).

The overrun of final product was calculated on a weight basis using a formula described by Akin et al. (2007).

Overrun $=[$ (the weight of a known volume of the mixture

- the weight of the equal volume of ice cream) /

the weight of the equal volume of ice cream] $\times 100$

Lipid oxidation determination. Malon dialdehyde (MDA), a secondary product of lipid oxidation, is formed form the decomposition of peroxides of Polyunsaturated Fatty Acids (PUFA) and is associated with the development of rancidity and oxidative deterioration. One mole of MDA reacts with 2 moles of thiobarbituric acid (TBA) to give a pink condensation (Kahraman and Ustunol, 2012).

The lipid oxidation was evaluated by TBA test according to Rosmini et al. (1996) with the following modification: A mixture of $1 \mathrm{~g}$ of sample, $5 \mathrm{ml}$ of $(0.02 \mathrm{M})$ TBA and $10 \mathrm{ml}$ of $10 \%$ TCA was centrifuged for $5 \mathrm{~min}$ at $3500 \mathrm{rpm}$. The supernatant was filtered by Whatman paper (no. 1) and an aliquot of $8 \mathrm{ml}$ of the filtrate was melted in a boiling water bath for $35 \mathrm{~min}$. The absorbance was measured in $532 \mathrm{~nm}$ after the color development. The degree of oxidation was determined at the beginning of the process and at every 30 days up to the last period of storage ( 90 days).

The results were reported as milligrams of MDA per kilogram of ice cream.

Viscosity test. The viscosities $[\mathrm{cP}]$ of ice creams were determined at $25^{\circ} \mathrm{C}$ using a digital viscometer (Model RVT; Brookfield Engineering Laboratories, Stoughton, MA, USA) at a constant speed (25 rpm) with the spindle number 3 .

Melting test. First dripping and complete melting times were measured according to Güven and Karaca (2002). $25 \mathrm{~g}$ of tempered samples were left to melt (at room temperature, $20^{\circ} \mathrm{C}$ ) on a $0.2 \mathrm{~cm}$ wire mesh screen above a beaker. First dripping and complete melting times of samples were determined as minutes one week after the production and at the end of the storage time.

Texture analysis. The hardness, cohesiveness and adhesiveness were measured using a texture analyzer (CT3 Texture Analyzer; Brookfield Engineering Laboratories), which was equipped to a stainless cylindrical probe $(6.0 \mathrm{~mm}$ diameter, $35 \mathrm{~mm}$ height). The sample (shape: block, length: $40.00 \mathrm{~mm}$, width: $60.00 \mathrm{~mm}$, depth: $40.00 \mathrm{~mm}$, temperature: $4^{\circ} \mathrm{C}$ ) was compressed twice with the probe to $50 \%$ of its height at $2 \mathrm{~mm} / \mathrm{s}$ rate. The ice cream samples were analyzed in triplicate.

\section{Enumeration of probiotic micro-organism}

The viability of Lactobacillus casei in the ice creams was determined following 1, 30, 60 and 90 days of storage at $-18^{\circ} \mathrm{C}$. The samples were cultured in De man, Rogosa, Sharpe agar medium (MRS agar, Merck, Darmstadt, Germany) containing 2 g/l Lithium chloride and $3 \mathrm{~g} / 1$ sodium propionate (LP-MRS-agar).

Enumeration of probiotic bacteria was achieved as described by Lima et al. (2009). All cultured plates of Lactobacillus casei were incubated at $37^{\circ} \mathrm{C}$ for $72 \mathrm{~h}$ under the aerobic conditions. The averages of all results were expressed as colony forming units per gram of sample $[\mathrm{CFU} / \mathrm{g}]$. 


\section{Sensory evaluations}

The organoleptic properties of ice creams were assessed by 30 (60\% men, 40\% women, aged 22-52) expert panelists at Ramak Dairy Company (Shiraz, Iran) after 1 and 90 days storage at $-18^{\circ} \mathrm{C}$. The flavor, texture, color and mouth feel of the samples were evaluated on a five point scale, with score 4 indicating 'excellent' and score 0 representing 'unacceptable' for human use as described by the Institute of Standards and Industrial Research of Iran (Hashemi et al., 2015).

\section{Statistical analysis}

Three replicates were carried out for all measurements. The data were analyzed using SPSS for Windows version 20 (SPSS Inc., Chicago, IL, USA). The analysis of variance (ANOVA) was used to determine the significant differences among the treatments for physicochemical parameters and the viability of the probiotic micro-organism. Duncan's post hoc test was applied to compare the means when the effect was significant. The sensory data were analyzed by the nonparametric Kruskal-Wallis test, followed by Mann-Whitney $\mathrm{U}$ test as a post hoc test. $P<0.05$ was considered as a level of significance.

\section{RESULTS AND DISCUSSION}

A gradual decrease in the $\mathrm{pH}$ of ice cream samples were observed during the storage at $-18^{\circ} \mathrm{C}$ for 3 months $(p<0.05)$. The lowest $\mathrm{pH}$ was related to the zinc fortified ice cream group. The $\mathrm{pH}$ of ice cream samples are given in the Table 1 . The decrease of $\mathrm{pH}$ is due to the metabolic activity of the microflora (producing lactic and/or acetic acid via the Embden-Meyerhof-Parnas pathway). Seleet et al. (2011) reported that the $\mathrm{pH}$ of fortified fermented milk with zinc and probiotic was decreased during the storage.

Han et al. (2012) added $\mathrm{Cu}^{2+}$ to whole milk before fermentation. They showed that $\mathrm{Cu}^{2+}$ at the concentration of $1.25 \mathrm{mg} / \mathrm{kg}$ could reduce the post acidification of fermented milk effectively. No significant effect on neither the fermentation time nor the viable counts of $S$. thermophilus $(P>0.05)$ was showed compared with the control sample.

The result of present study indicated that the titratable acidity of ice cream in all groups was increased during 3 months of storage $(p<0.05)$. The highest acidity was related to zinc fortified ice cream group. The titratable acidity of ice cream samples are given in the Table 2.

Abd-Rabou et al. (2010) reported that the acidity of Edam cheese fortified by dietary zinc salts has been increased during the ripening in all the cheese samples. Salgueiro et al. (2000), also reported that the addition of zinc salts could increase the acidity.

The TBA assay is commonly used as a marker for the oxidative damage and to determine the freshness of food (Shamberger et al., 1977). Zinc has been reported to inhibit the free radical lipid peroxidation in biological systems (Girotti et al., 1985). Zinc protects membranes from the iron-initiated lipid oxidation by occupying the negatively charged sites with the potential iron-binding capacity, or by serving as a free radical scavenger (Fang et al., 2002).

Table 1. Mean $\pm \mathrm{SD}$ of $\mathrm{pH}$ determination in the ice creams that stored at $-18^{\circ} \mathrm{C}$ for 3 months

\begin{tabular}{ccccc}
\hline & \multicolumn{3}{c}{ Group } \\
\cline { 2 - 5 } Day & control & $\begin{array}{c}\text { zinc for tified ice } \\
\text { cream }\end{array}$ & probiotic ice cream & $\begin{array}{c}\text { zinc for tified and } \\
\text { probiotic ice cream }\end{array}$ \\
\hline 1 & $6.64 \pm 0.01^{\mathrm{Cb}}$ & $6.59 \pm 0.02^{\mathrm{Da}}$ & $6.56 \pm 0.02^{\mathrm{Ca}}$ & $6.68 \pm 0.02^{\mathrm{Cc}}$ \\
30 & $6.54 \pm 0.02^{\mathrm{Ba}}$ & $6.53 \pm 0.02^{\mathrm{Ca}}$ & $6.54 \pm 0.03^{\mathrm{BCa}}$ & $6.63 \pm 0.02^{\mathrm{Bb}}$ \\
60 & $6.51 \pm 0.02^{\mathrm{ABa}}$ & $6.51 \pm 0.01^{\mathrm{Ba}}$ & $6.50 \pm 0.01^{\mathrm{Aa}}$ & $6.61 \pm 0.02^{\mathrm{ABb}}$ \\
90 & $6.48 \pm 0.02^{\mathrm{Aa}}$ & $6.47 \pm 0.02^{\mathrm{Aa}}$ & $6.47 \pm 0.02^{\mathrm{Aa}}$ & $6.58 \pm 0.02^{\mathrm{Ab}}$ \\
\hline
\end{tabular}

Means in the same column denoted by different capital letters were significantly different $(P<0.05)$. Means in the same row denoted by different small letters were significantly different $(P<0.05)$. 
Gheisari, H. R., Ahadi, L., Khezli, S., Dehnavi, T. (2016). Properties of ice-cream fortified with zinc and Lactobacillus casei. Acta Sci. Pol. Technol. Aliment., 15(4), 367-377. DOI: 10.17306/J.AFS.2016.4.35

Table 2. Mean $\pm \mathrm{SD}$ of acidity determination in the ice creams that stored at $-18^{\circ} \mathrm{C}$ for 3 months

\begin{tabular}{ccccc}
\hline & \multicolumn{3}{c}{ Group } \\
\cline { 2 - 5 } Day & control & $\begin{array}{c}\text { zinc fortified } \\
\text { ice cream }\end{array}$ & probiotic ice cream & $\begin{array}{c}\text { zinc fortified and } \\
\text { probiotic ice cream }\end{array}$ \\
\hline 1 & $0.07 \pm 0.02^{\mathrm{Aa}}$ & $0.08 \pm 0.01^{\mathrm{Aa}}$ & $0.09 \pm 0.01^{\mathrm{Aa}}$ & $0.08 \pm 0.02^{\mathrm{Aa}}$ \\
30 & $0.10 \pm 0.03^{\mathrm{ABa}}$ & $0.10 \pm 0.02^{\mathrm{ABa}}$ & $0.11 \pm 0.03^{\mathrm{ABa}}$ & $0.11 \pm 0.03^{\mathrm{ABa}}$ \\
60 & $0.12 \pm 0.01^{\mathrm{Ba}}$ & $0.17 \pm 0.02^{\mathrm{Cb}}$ & $0.13 \pm 0.02^{\mathrm{Ba}}$ & $0.12 \pm 0.02^{\mathrm{ABa}}$ \\
90 & $0.11 \pm 0.01^{\mathrm{Ba}}$ & $0.13 \pm 0.01^{\mathrm{Ba}}$ & $0.12 \pm 0.01^{\mathrm{Ba}}$ & $0.16 \pm 0.01^{\mathrm{Cb}}$ \\
\hline
\end{tabular}

Means in the same column denoted by different capital letters were significantly different $(P<0.05)$. Means in the same row denoted by different small letters were significantly different $(P<0.05)$.

Zinc may also act synergistically with water soluble antioxidants to protect membranes from oxidation (Zago and Oteiza, 2001). Therefore, our intent was to determine if zinc would also inhibit the lipid oxidation in a food system.

Table 3 shows the TBA results of the samples over the 3 months of storage. The TBA values of the ice creams were increased during the storage time. Our results showed significant differences between different groups and times $(p<0.05)$.

The results showed the highest TBA values in the fortified zinc ice creams and the lowest in the probiotic ice creams.

Kahraman and Ustunol (2012) reported that in the zinc fortified cheddar cheese, the TBA values was increased and then eventually decreased over the ripening time. In the study of Abd-Rabou et al. (2010), the TBA values of the zinc fortified Edam cheese was increased during the ripening period. Similar results were reported by other researchers (Jackson and Lee, 1991; Kim et al., 2003; Kwak et al., 2003).

The amount of air incorporated (also referred as overrun) varies from $20 \%$ for artisanal ice cream (gelato) to $50 \%$ or $100 \%$ for industrial frozen dairy desserts (Marshall et al., 2003). In the study of Ferraz et al. (2012), it was demonstrated that an overrun of $45 \%$ or less does not modify the viable count of $L$. acidophilus. L. rhamnosus significantly and $L$. casei exhibited a higher oxygen tolerance than $L$. acidophilus in unfermented ice creams (Homayouni et al., 2012; Abghari et al., 2011).

Probiotic bacteria have different strategies to cope with the stress caused by oxygen. For instance, they can avoid the formation of oxidative species by

Table 3. Mean $\pm \mathrm{SD}$ of TBA determination in the ice creams that stored at $-18^{\circ} \mathrm{C}$ for 3 months, $\mathrm{mg} / \mathrm{kg}$

\begin{tabular}{ccccc}
\hline & \multicolumn{3}{c}{ Group } \\
\cline { 2 - 5 } Day & control & $\begin{array}{c}\text { zinc fortified } \\
\text { ice cream }\end{array}$ & probiotic ice cream & $\begin{array}{c}\text { zinc fortified and } \\
\text { probiotic ice cream }\end{array}$ \\
\hline 1 & $0.90 \pm 0.18^{\mathrm{Aab}}$ & $1.31 \pm 0.06^{\mathrm{Ac}}$ & $0.80 \pm 0.05^{\mathrm{Aa}}$ & $1.12 \pm 0.06^{\mathrm{Ab}}$ \\
30 & $1.82 \pm 0.15^{\mathrm{Bab}}$ & $2.35 \pm 0.12^{\mathrm{Bc}}$ & $1.65 \pm 0.04^{\mathrm{Ba}}$ & $1.93 \pm 0.13^{\mathrm{Bb}}$ \\
60 & $2.34 \pm 0.01^{\mathrm{Ca}}$ & $2.90 \pm 0.05^{\mathrm{Cc}}$ & $2.70 \pm 0.06^{\mathrm{Cb}}$ & $2.87 \pm 0.04^{\mathrm{Cc}}$ \\
90 & $3.55 \pm 0.18^{\mathrm{Dba}}$ & $3.95 \pm 0.14^{\mathrm{Dc}}$ & $3.22 \pm 0.29^{\mathrm{D}}$ & $3.73 \pm 0.02^{\mathrm{Db}}$ \\
\hline
\end{tabular}

Means in the same column denoted by different capital letters were significantly different $(P<0.05)$. Means in the same row denoted by different small letters were significantly different $(P<0.05)$. 
Table 4. Mean $\pm \mathrm{SD}$ of viscosity determination in the ice creams that stored at $-18^{\circ} \mathrm{C}$ for 3 months

\begin{tabular}{ccccc}
\hline & \multicolumn{3}{c}{ Group } \\
\cline { 2 - 5 } Day & control & $\begin{array}{c}\text { zinc fortified } \\
\text { ice cream }\end{array}$ & probiotic ice cream & $\begin{array}{c}\text { zinc fortified and } \\
\text { probiotic ice cream }\end{array}$ \\
\hline 1 & $2432 \pm 34.48^{\mathrm{Bd}}$ & $2056 \pm 22.62^{\mathrm{Ab}}$ & $1950 \pm 31.01^{\mathrm{Ca}}$ & $2213 \pm 43.15^{\mathrm{Dc}}$ \\
30 & $2381 \pm 90.31^{\mathrm{Bc}}$ & $2147 \pm 181.01^{\mathrm{Ac}}$ & $1532 \pm 47.48^{\mathrm{Ba}}$ & $1730 \pm 34.42^{\mathrm{Cb}}$ \\
60 & $1886 \pm 164.27^{\mathrm{Ad}}$ & $1844 \pm 266.48^{\mathrm{Ac}}$ & $1254 \pm 60.50^{\mathrm{Aa}}$ & $1460 \pm 48.08^{\mathrm{Bb}}$ \\
90 & $1752 \pm 196.29^{\mathrm{Ac}}$ & $1714 \pm 354.48^{\mathrm{Abc}}$ & $1114 \pm 90.50^{\mathrm{Aa}}$ & $1324 \pm 86.03^{\mathrm{Ab}}$ \\
\hline
\end{tabular}

Means in the same column denoted by different capital letters were significantly different $(P<0.05)$. Means in the same row denoted by different small letters were significantly different $(P<0.05)$.

Table 5. Mean $\pm \mathrm{SD}$ of melting rate determination in the ice creams that stored at $-18^{\circ} \mathrm{C}$ for 3 months

\begin{tabular}{ccccc}
\hline & \multicolumn{3}{c}{ Group } \\
\cline { 2 - 5 } Day & control & $\begin{array}{c}\text { zinc fortified } \\
\text { ice cream }\end{array}$ & probiotic ice cream & $\begin{array}{c}\text { zinc fortified and } \\
\text { probiotic ice cream }\end{array}$ \\
\hline 1 & $0.72 \pm 0.01^{\mathrm{Ba}}$ & $0.73 \pm 0.01^{\mathrm{Ca}}$ & $0.73 \pm 0.01^{\mathrm{Ca}}$ & $0.73 \pm 0.01^{\mathrm{Ca}}$ \\
30 & $0.71 \pm 0.01^{\mathrm{Ba}}$ & $0.71 \pm 0.01^{\mathrm{Ba}}$ & $0.71 \pm 0.01^{\mathrm{BCa}}$ & $0.72 \pm 0.01^{\mathrm{Ca}}$ \\
60 & $0.70 \pm 0.02^{\mathrm{Bb}}$ & $0.70 \pm 0.01^{\mathrm{ABb}}$ & $0.70 \pm 0.02^{\mathrm{Bb}}$ & $0.66 \pm 0.02^{\mathrm{Ba}}$ \\
90 & $0.65 \pm 0.01^{\mathrm{Ab}}$ & $0.68 \pm 0.01^{\mathrm{Ac}}$ & $0.67 \pm 0.01^{\mathrm{Ac}}$ & $0.62 \pm 0.01^{\mathrm{Aa}}$ \\
\hline
\end{tabular}

Means in the same column denoted by different capital letters were significantly different $(P<0.05)$. Means in the same row denoted by different small letters were significantly different $(P<0.05)$.

Table 6. Mean \pm SD of $\log$ cfu/g of Lactibacillus casei count in the ice creams that stored at $-18^{\circ} \mathrm{C}$ for 3 months

\begin{tabular}{rcc}
\hline & \multicolumn{2}{c}{ Group } \\
\cline { 2 - 3 } Day & zinc fortified and probiotic ice cream & probiotic ice cream \\
\hline 1 & $8.33 \pm 0.11^{\mathrm{Ba}}$ & $8.71 \pm 0.06^{\mathrm{Db}}$ \\
30 & $8.14 \pm 0.25^{\mathrm{ABa}}$ & $8.48 \pm 0.08^{\mathrm{Cb}}$ \\
60 & $7.80 \pm 0.27^{\mathrm{Aa}}$ & $8.23 \pm 0.10^{\mathrm{Bb}}$ \\
90 & $7.30 \pm 0.30^{\mathrm{Aa}}$ & $7.80 \pm 0.12^{\mathrm{Ab}}$ \\
\hline
\end{tabular}

Means in the same column denoted by different capital letters were significantly different $(P<0.05)$. Means in the same row denoted by different small letters were significantly different $(P<0.05)$. 
Table 7. Mean $\pm \mathrm{SD}$ of overrun in the ice cream samples, $\%$

\begin{tabular}{cccc}
\hline \multicolumn{3}{c}{ Group } \\
\hline control & $\begin{array}{c}\text { zinc fortified } \\
\text { ice cream }\end{array}$ & probiotic ice cream & $\begin{array}{c}\text { zinc fortified and } \\
\text { probiotic ice cream }\end{array}$ \\
\hline $63.24 \pm 13.3^{\mathrm{a}}$ & $63.26 \pm 2.97^{\mathrm{a}}$ & $63.27 \pm 1.46^{\mathrm{a}}$ & $63.12 \pm 3.2^{\mathrm{a}}$ \\
\hline
\end{tabular}

Means in the same row denoted by different small letters were significantly different $(P<0.05)$.

eliminating them through degradation or they can repair the damage caused by such exposure (Van de Guchte et al., 2002).

The overrun of the ice cream samples was not significantly different compared to the control formulation $(p>0.05$; Table 7). This was in agreement with the results of a study, Akin et al. (2007) who found that the addition of inulin had no significant effect on the overrun values of the samples. Overrun did not have influence on the survival of probiotic bacteria.

The viscosity was decreased in all groups of ice creams during the storage period $(p<0.05)$. The highest amount of viscosity [cP] was related to the control and the lowest belonged to the probiotic groups. Zinc did not have influence on the viscosity of ice cream.

Our results indicated that melting rate was decreased by the addition of probiotic microorganism or zinc in the formulation $(p<0.05)$. El-Nagar et al. (2002) reported that the addition of inulin reduced the melting rate of yoghurt ice cream.

In the present study, when probiotic and zinc were added in the formulation, no significant difference was verified for hardness $[\mathrm{gF}]$, cohesiveness $[\mathrm{mJ}]$ and adhesiveness of the ice cream samples. Our results are consistent with the study by Kahraman and Ustunol (2012) who reported that the hardness of zinc fortified cheese was not significantly different compared with the control cheese.

The viable counts of Lactobacillus casei are shown in Table 6. There was significant decrease in the viable counts during the storage period in all the experimental groups. The viable counts of Lactobacillus casei in all samples were higher than that of the recommended minimum limit of $6 \mathrm{Log} \mathrm{cfu} / \mathrm{g}$ to have the beneficial effects on the consumer's health (Hekmat and McMahon, 1997). Probiotic and zinc fortified group showed a higher viable count than the probiotic ice cream group. However, the mechanical stresses of mixing and freezing processes caused by the formation of ice crystals and by scraping of the cylinder wall by the blade of freezer, and also the incorporation of oxygen into the mix, may have resulted in a further decrease in the viable bacterial counts (Cruz et al., 2009; Homayouni et al., 2012; Turgut and Cakmakci, 2009).

The findings of present study resembled to those previously reported (Akalin and Erişir, 2008; Christiansen et al., 1996; Hagen and Narvhus, 1999), which demonstrated the significant decrease in the bacterial counts due to the freezing process.

This reduction may be less or more from those of other studies, which were probably due to the different production technologies, different formulations and different $\mathrm{pH}$ values of mixes.

The sensory scores of the ice cream samples are given in Figure 2. Experimental sensory work is simpler and has been shown to be more cost effective than just-about-right (JAR) scales without losses of consumer acceptability.

The interaction of "tasty" compounds with specialized receptors in taste buds of the tongue and palate is transduced via electrical excitation of taste receptor cells. This excitation is transmitted to the brain, where the final representation of each taste modality is formed (Talavera et al., 2007). Increasing the temperature of consumption and the fat content have an inverse effect on the ideal sweetening power in whole milk beverages.

The scores of the organoleptic evaluation showed that the addition of probiotic and zinc had no negative effect on the sensory properties of ice cream.

The total evaluation in terms of color, texture, flavor and mouth feel of all samples were good and didn't have any concerning flavor during the storage period. None of the ice creams were judged to be crumbly, weak, flatty or sandy. Our sensory results are similar with a previous study reported by Kahraman and 
Gheisari, H. R., Ahadi, L., Khezli, S., Dehnavi, T. (2016). Properties of ice-cream fortified with zinc and Lactobacillus casei. Acta Sci. Pol. Technol. Aliment., 15(4), 367-377. DOI: 10.17306/J.AFS.2016.4.35

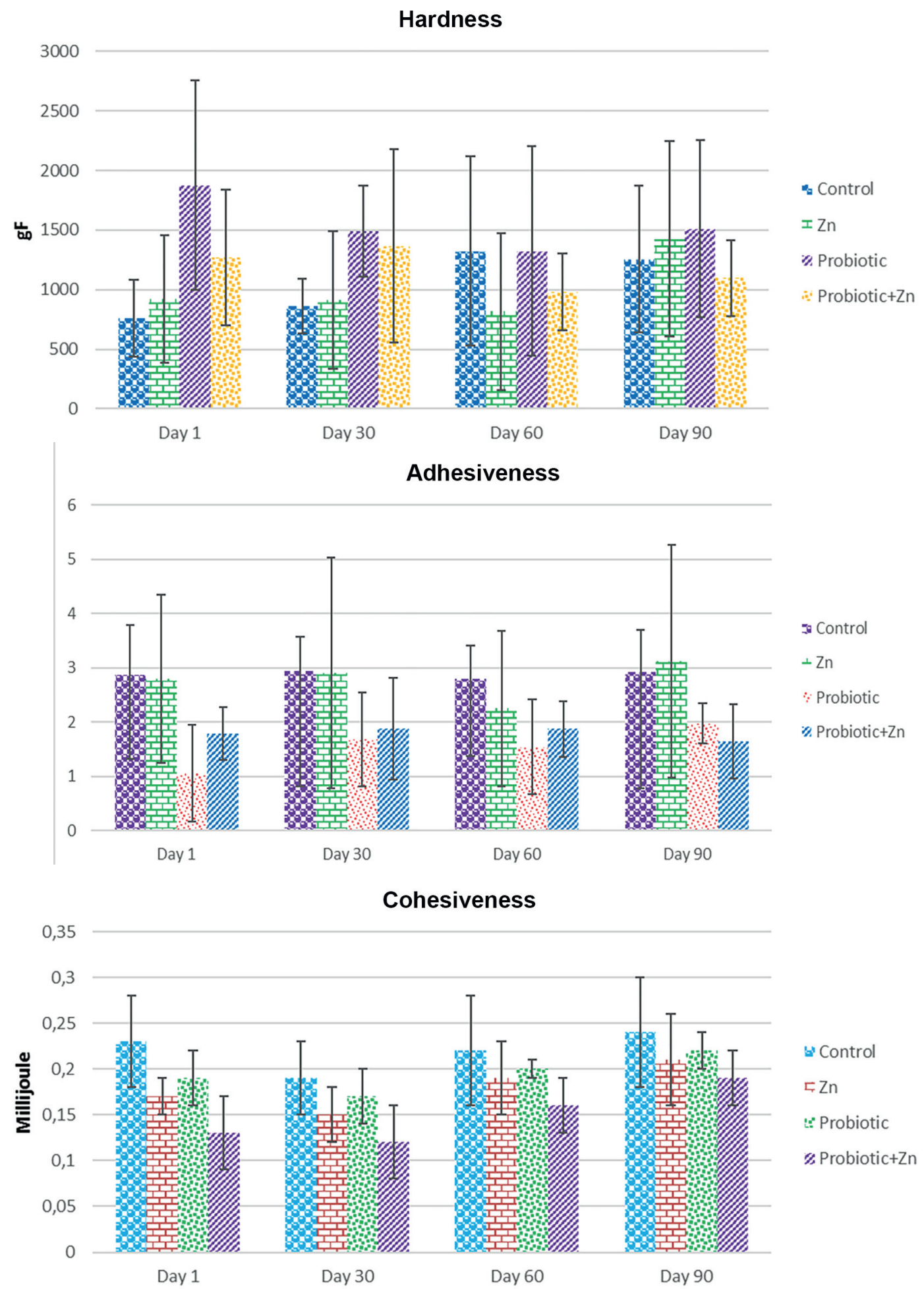

Fig. 1. Mean $\pm \mathrm{SD}$ of textural characteristics in the ice creams that stored at $-18^{\circ} \mathrm{C}$ for 3 months 


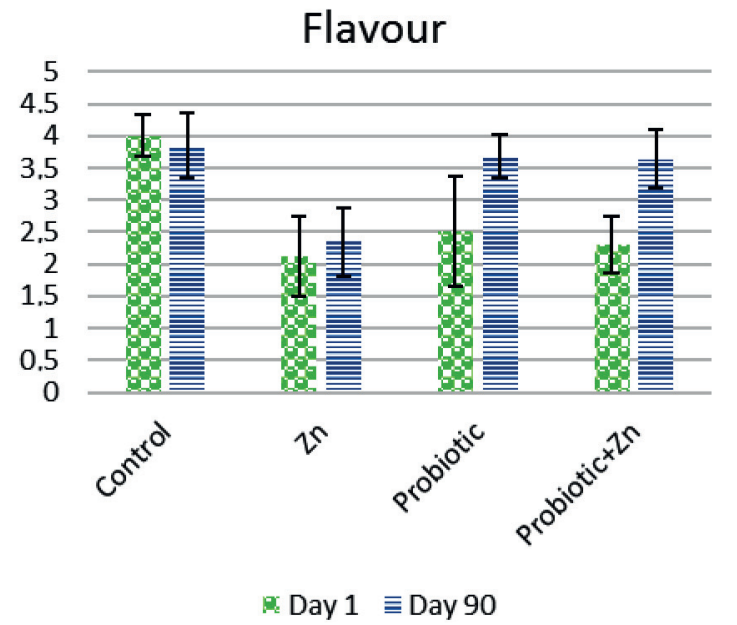

Color

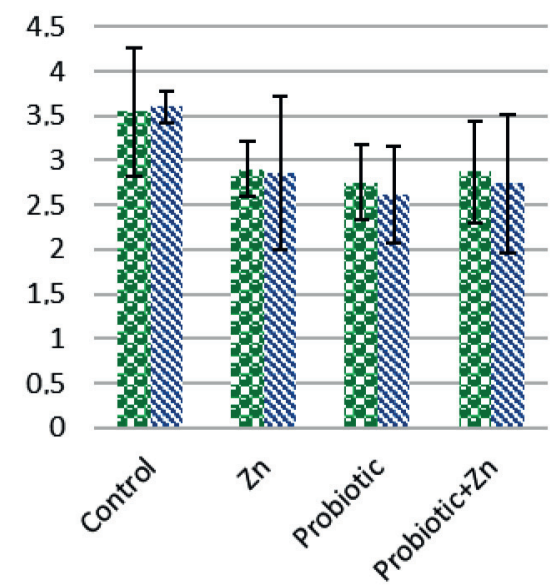

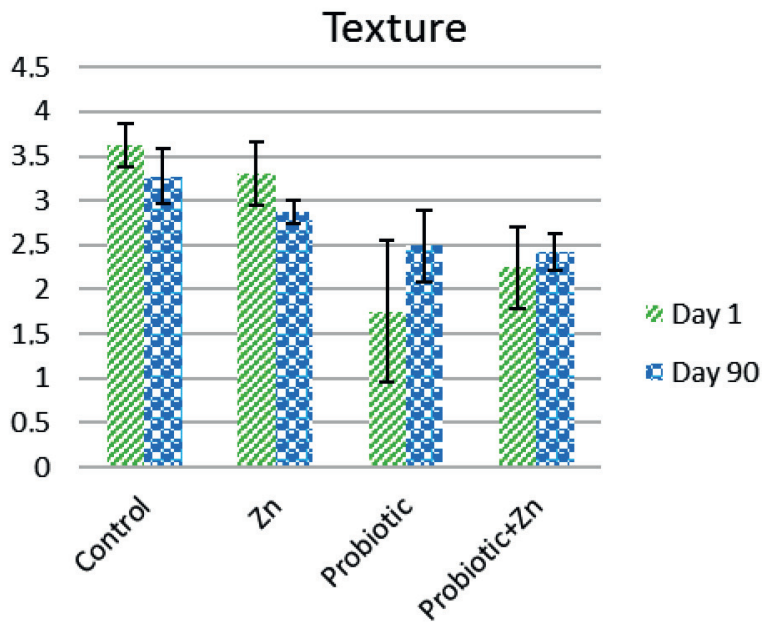

Mouth feel

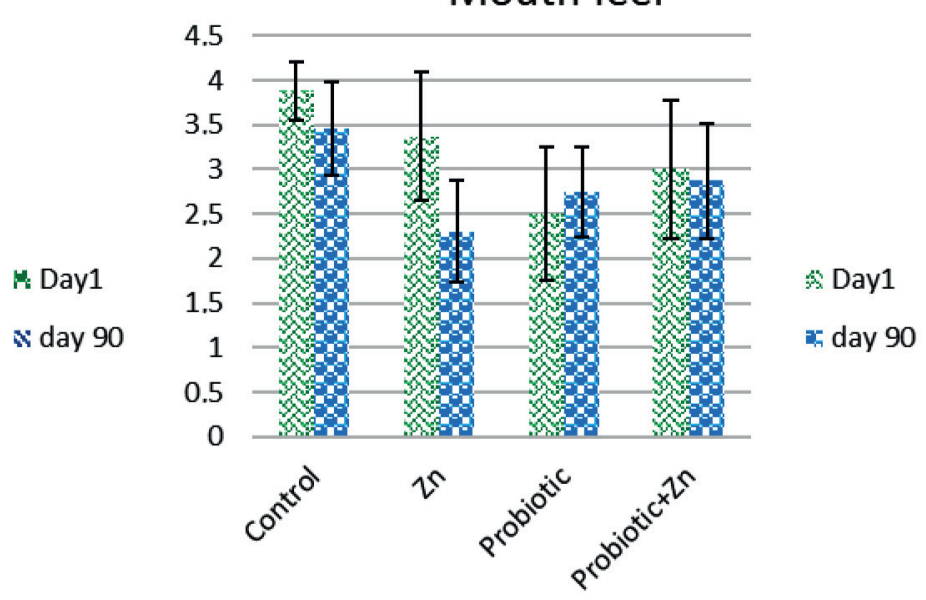

Fig. 2. Sensory evaluation of different groups of ice creams at days 1 and 90 of storage

Ustunol (2012) and Abd-Rabou et al. (2010), which also claimed that zinc sulfate didn't affect the sensory attributes of the fortified products.

\section{CONCLUSIONS}

This study showed that the fortification of ice cream with zinc sulfate is a suitable approach to fortify this dairy product without any significant negative changes in the quality of ice cream. Zinc-fortified ice cream could be an excellent food source for the replenishment of zinc levels in people with the zinc deficiency risk. This should provide the elderly groups the adequate amount of zinc and vegetarians who do not consume meat but still consume dairy products with an additional food source that is high in zinc level. As a final conclusion, the commercial production of the zinc fortified probiotic ice cream is recommended as a healthy and functional food.

\section{REFERENCES}

Abd-Rabou, N. S., Zaghloul, A. H., Seleet, F. L., El-Hofi, M. A. (2010). Properties of Edam cheese fortified by dietary zinc salts. J. Am. Sci., 6, 10, 441-446.

Abghari, A., Sheikh-Zeinoddin, M., Soleimanian-Zad, S. (2011). Nonfermented cream as a carrier for Lactobacillus acidophilus and Lactobacillus rhamnosus. Int. J. Food Sci. Technol., 46, 84-92. 
Akin, M. B, Akin, M. S., Kirmaci, Z. (2007). Effects of inulin and sugar levels on the viability of yogurt and probiotic bacteria and the physical and sensory characteristics in probiotic ice-cream. Food Chem., 104, 1, 93-99.

Akalin, A., Erişir, D. (2008). Effects of inulin and oligofructose on the rheological characteristics and probiotic culture survival in low-fat probiotic ice cream. J. Food Sci., 73, 4, 184-188.

AOAC (2010). Official methods of analysis. 18th edition. 3rd revision. Association of Official Analytical Chemists.

Christiansen, P. S., Edelsten, D., Kristiansen, J. R., Nielsen, E. W. (1996). Some properties of ice cream containing Bifidobacterium bifidum and Lactobacillus acidophilus. Milchwissenschaft, 51, 9, 502-504.

Cruz, A. G., Antunes, A. E., Sousa, A. L. O., Faria, J. A., Saad, S. M. (2009). Ice-cream as a probiotic food carrier. Food Res. Int., 42, 9, 1233-1239.

Degheidi, M. A., Abd-Rabou, N. S. (1998). Effect of zinc salts on the ripening process of Ras cheese. 7 Egyptian Conference for Dairy Science and Technology (pp. 403416). Cairo (Egypt).

El-Nagar, G., Clowes, G., Tudorica, C. M., Kuri, V., Brennan, C. S. (2002). Rheological quality and stability of yog-ice cream with added inulin. Int. J. Dairy Technol., 55, 89-93. DOI: 10.1046/j.1471-0307.2002.00042.x

Fang, Y. Z., Yang, S., Wu, G. (2002). Free radicals, antioxidants, and nutrition. Nutrition, 18, 10, 872-829.

Ferraz, J. L., Cruz, A. G., Cadena, R. S., Freitas, M. Q., Pinto, U. M., Carvalho, C. C., ..., Bolini, H. M. (2012). Sensory acceptance and survival of probiotic bacteria in ice cream produced with different overrun levels. J. Food Sci., 77, 1, S24-28.

Food and Nutrition Board and Institute of Medicine (2001). Dietary reference intakes for vitamin A, vitamin $\mathrm{K}$, boron, chromium, copper, iodine, iron, manganese, molybdenum, nickel, silicon, vanadiumand zinc (pp. 442-501). Washington, DC: Standing Committee on the Scientific Evaluation of Dietary Reference Intakes, National Academy Press.

Gibson, G. R., Probert, H. M., Van Loo, J., Rastall, R. A., Roberfroid, M. B. (2004). Dietary modulation of the human colonic microbiota: updating the concept of prebiotics. Nutr. Res. Rev., 17, 2, 259-275.

Girotti, A. W., Thomas, J. P., Jordan, J. E. (1985). Inhibitory effect of zinc (II) on free radical lipid peroxidation in erythrocyte membranes. J. Free Rad. Biol. Med., 1, 5, 395-401.

Güven, M., Karaca, O. B. (2002) The effects of varying sugar content and fruit concentration on the physical properties of vanilla and fruit ice-cream-type frozen yogurts. Int. J. Dairy Technol., 55, 27-31.

Hagen, M., Narvhus, J. (1999). Production of ice cream containing probiotic bacteria. Milchwissenschaft, 54, 5, 265-268.

Han, X., Zhang, L., Du, M., Yi, H., Li, J., Zhang, L. (2012). Effects of copper on the post acidification of fermented milk by St. thermophiles. J. Food Sci., 77, 1, M25-28.

Hashemi, M., Gheisari, H. R., Shekarforoush, S. (2015). Preparation and evaluation of low-calorie functional ice cream containing inulin, lactulose and Bifidobacterium lactis. Int. J. Dairy Techn., 68, 2, 183-189.

Hasler, C. (2002). Functional food: benefits, concerns and challenges. J. Nutr., 132, 3772-3781.

Hekmat, S., McMahon, D. J. (1997). Manufacture and quality of iron-fortified yogurt. J. Dairy Sci., 80, 12, 3114-3122.

Hermansen, J. E., Larsen, T., Andersen, J. (1995). Does zinc play a role in the resistance of milk to spontaneous lipolysis? Int. Dairy J., 5, 5, 473-481.

Homayouni, A., Azizi, A., Javadi, M., Mahdipour, S., Ejtahed, H. (2012). Factors influencing probiotic survival in ice cream: a review. Int. J. Dairy Sci., 7, 1-10.

Hotz, C., DeHaene, J., Woodhouse, L. R., Villalpando, S., Rivera, J. A., King, J. C. (2005). Zinc absorption from zinc oxide, zinc sulfate, zinc oxide EDTA or sodiumzinc EDTA does not differ when added as fortificants to maize tortillas. J. Nutr., 135, 1102-1105.

Hunt, C. D., Nielsen, F. H. (2009). nutritional aspects of minerals in bovine and human milk. In P. L. H. McSweeney, P. F. Fox (Eds.), Advanced dairy chemistry (vol. 3, pp. 420-422). New York, NY: Springer.

Jackson, L. S., Lee, K. (1991). Microencapsulated iron for food fortification. J. Food Sci., 56, 4, 1047-1050.

Jayasekara, S., Samarajeewa, U., Jayakody, A. (1992). Trace metals in foods of animal origin in Sri Lanka. ASEAN Food J. (Malaysia), 7, 2, 105-107.

Jeejeebhoy, K. (2009). Zinc: An essential trace element for parenteral nutrition. Gastroenterology, 137, S7-S12.

Kahraman, O., Ustunol, Z. (2012). Effect of zinc fortification on Cheddar cheese quality. J. Dairy Sci., 95, 6, 2840-2847.

Kailasapathy, K., Sultana, K. (2003). Survival and [beta]-D-galactosidase activity of encapsulated and free Lactobacillus acidophilus and Bifidobacterium lactis in icecream. Austr. J. Dairy Techn., 58, 3, 223-227.

Kim, S., Ahn, J., Seok, J., Kwak, H. (2003). Microencapsulated iron for drink yogurt fortification. Asian-Austral. J. Anim. Sci., 16, 4, 581-587. 
Kwak, H., Ju, Y., Ahn, H., Ahn, J., Lee, S. (2003). Microencapsulated iron fortification and flavor development in Cheddar cheese. Asian-Austral. J. Anim. Sci., 16, 8, 1205-1211.

Lima, K. G. C., Kruger, M. F., Behrens, J., Destro, M. T., Landgraf, M., Franco, B. D. G. M. (2009). Evaluation of culture media for enumeration of Lactobacillus acidophilus, Lactobacillus casei and Bifidobacterium animalis in the presence of Lactobacillus delbrueckii subsp. bulgaricus and Streptococcus thermophilus. LWT Food Sci. Techn., 42, 2, 491-495.

Marshall, R. T., Goff, H. D., Hartesl, R. W. (2003). Ice cream. Springer.

Qin, Y., Melse-Boonstra, A., Shi, Z., Pan, X., Yuan, B., ..., Zhou M. (2009). Dietary intake of zinc in the population of Jiangsu Province, China. Asia Pac. J. Clin. Nutr., 18, 2, 193-199.

Rink, L., Gabriel, P. (2000). Zinc and the immune system. Proc. Nutr. Soc., 59, 4, 541-552.

Rosmini, M. R., Perlo, F., Perez-Alvarez, J. A., Pagan-Moreno, M. J., Gago-Gago, A., López-Santoveña, F., Aranda-Catalá, V. (1996). TBA test by an extractive method applied to 'pate'. Meat Sci., 42, 1, 103-110.

Salgueiro, M. J., Zubillaga, M., Lysionek, A., Sarabia, M. I., Caro, R., De Paoli, T., ..., Boccio, J. (2000). Zinc as an essential micronutrient: a review. Nutr. Res., 20, 5, 737-755.

Saper, R. B., Rash, R. (2009). Zinc: an essential micronutrient. Am. Family Phys., 79, 9, 768-772.

Saxelin, M., Korpela, R., Mäyrä-Mäkinen, A., Mattila-Sandholm, T., Saarela, M. (2003). Introduction: classifying functional dairy products. In: T. Mattila-Sandholm,
M. Saarela (Eds), Functional dairy products (pp. 1-16). England: CRC Press, Woodhead Publ.

Seleet, F. L., El-Kholy, W. I., Abd-Rabou, N. S. (2011). Evaluation of milk drinks fermented by probiotic bacteria and fortified with zinc salts. Pol. J. Food Nutr. Sci., $61,1,55-60$.

Shah, N., Ravula, R. (2000). Microencapsulation of probiotic bacteria and their survival in frozen fermented dairy desserts. Aust. J. Dairy Techn., 55, 3, 139-144.

Shamberger, R. J., Shamberger, B. A., Willis, C. E. (1977). Malonaldehyde content of food. J. Nutr., 107, 8, 1404-1409.

Simmer, K., Thompson, R. (1985). Zinc in the fetus and newborn. Acta Paediatr., 319, 158-163.

Talavera, K., Ninomiya, Y., Winkel, C., Voets, T., Nilius, B. (2007). Influence of temperature on taste perception. Cell Mol. Life Sci., 64(4), 377-381.

Turgut, T., Cakmakci, S. (2009). Investigation of the possible use of probiotics in ice cream manufacture. Int. J. Dairy Techn., 62, 3, 444-451.

Van de Guchte, M., Serror, P., Chervaux, C., Smokvina, T., Ehrlich, S. D., Maguin, E. (2002). Stress responses in lactic acid bacteria. Antonie van Leeuwenhoek, 82, 187-216.

Walingo, M. K. (2009). Indigenous food processing methods that improve zinc absorption and bioavailability of plant diets consumed by the Kenyan population. Afric. J. Food Agric. Nutr. Devel., 9, 1, 523-535.

Zago, M. P., Oteiza, P. I. (2001). The antioxidant properties of zinc: interactions with iron and antioxidants. Free Rad. Biol. Med., 31, 2, 266-274. 